\title{
CASH FLOW RELATED INDICATORS OF BUSINESS SUSTAINABILITY
}

\author{
Nicolette Brouwer* \\ University of the Western Cape \\ nbrouwer@mweb.co.za
}

November 2011

\begin{abstract}
The purpose of this research is to generate cash- and value-flow-related indicators of business sustainability. In order to facilitate a meaningful generation of such indicators, an understanding of business sustainability with reference to cash and value flow is articulated through a conceptual analysis. The research is conducted within an interpretive accounting research paradigm in which the social context of accounting is considered.

A literature analysis demonstrates that business sustainability is found to encompass balanced stakeholder engagement, transparency, economic efficiency, creativity and adaptability to change. An analytical study is conducted on four sustainability and valuation models which are currently used by practitioners. The purpose of the analytical study is to explore and generate cash-and value-flow-related indicators of business sustainability within key business focus areas that are informed by fundamental financial and corporate governance principles. The research therefore makes a strong case for a holistic approach to achieving and measuring business sustainability.
\end{abstract}

\section{Keywords}

Business sustainability, stakeholders, transparency, creativity, economic efficiency, adaptability, cash- and value-flow-related indicators, holism, principles of ecology, overall ordered movement.

*Ms Nicolette Brouwer is a senior lecturer in the department of Accounting at University of the Western Cape, South Africa. 


\section{INTRODUCTION}

Business sustainability is an area of growing interest and focus. It addresses both what is important for the survival of the planet and what business needs to do to survive in a changing world. This research addresses the issue of business sustainability in a holistic context and proposes that business needs to cooperate with the dynamics of nature (Lambrechts, 2009) and overall cosmic movement (Nicolescu, 2008) in order to sustain itself and contribute to overall planetary, human and business sustainability.

The triple-bottom-line reporting requirements, which are mandatory in some countries, and more recently the Framework for Integrated Reporting and the Integrated Report (IRC, 2011), do not necessarily induce a genuine shift to an internally generated sustainable management style, business strategy and ethos. Swilling (2001:22) expresses the concern that the triple-bottomline concept is so 'sexy' that businesses will automatically be committed to it, carrying the risk of it losing its real meaning as the harder issues are faced and triple bottom-line becomes another brief for the 'spin-doctors'. Shani, Sena and Olin (2003) concur and identify a need for a deeper, genuine and holistic understanding of sustainability. The King III Report (King III) reiterates that a substantial shift towards sustainability is required, and that incremental movements currently made are not adequate $($ IOD, 2009). In order to generate meaningful indicators of business sustainability, this research aims to reveal the true meaning and practical requirements of business sustainability.

The paper addresses this requisite shift to genuine business sustainability in practical terms, discussing the value creators of business, being specific intangible capital and the wealth generated by and contributing to these assets, comprising cash and value flow. Business is about ensuring that market demand is met by having the capital, relationships and ability to sustain cash flow to enable the generation of profit (Chow Hoi Hee, 2007). Burger and Hamman (1999) performed a study on the use of a cash-flow sustainable growth rate in addition to the traditional accounting sustainable growth rate. The cash-flow sustainable growth rate guards against growing a company into an unhealthy cash situation and considers non-cash components of working capital. Jarvis, Curran, Kitching and Lightfoot (1999) performed a survey on performance measures for small organisations in the United Kingdom in terms of which profit measures were found to be substantially less important as cash-flow indicators.

Cash flow is the movement of cash in and throughout a business community. Business is about process(es), about continually seeking to optimise the efficiency of the flow of value from the beginning to the end of the process, which includes recognising real value in the business process for all stakeholders (Savitz, 2006). The key is enhancing the flow of value, not just value. Value is not static, it is a movement. Based on the strength of the above message that cash flow is critical to sustainable growth, this research explores the link between cash and value flow and business sustainability and presents indicators that depict this. The cash- and value-flow indicators generated are for use by business and its stakeholders for the purpose of determining and assessing measures to enhance sustainability.

\section{RESEARCH PROBLEM AND PUESTIONS}

The primary problem aims to address what cash- and value-flow-related indicators of business sustainability are. The study will generate and explore cash-and value-flow indicators in the 
context of business sustainability for all stakeholders. To address the primary problem and generate indicators, the research questions are as follows:

- What are the understandings of business sustainability in a holistic sense?

- What is the relevance of cash/value flow to business sustainability?

- Why address all stakeholders as opposed to primarily the investor base?

- Should financial accounting not provide a more holistic communication?

- What are cash/value-flow-related indicators that reflect business sustainability?

These questions were created to support the primary problem. In order to facilitate the generation of meaningful sustainability indicators for the purpose of this research a holistic understanding of business sustainability and a valid link between cash and value flow and business sustainability were required. The nature of indicators generated will be informed by the understanding of business sustainability and relevance of cash and value flow to it. The need to address questions on the stakeholder perspective and holistic stakeholder communication were deemed necessary to provide a firm foundation for the generation of cash-and value-flowrelated indicators.

\section{RESEARCH METHODOLOGY AND DESIGN}

The research methodology is situated within the interpretive accounting research paradigm. Interpretive research seeks to understand and interpret (Babbie \& Mouton, 2001) and is based on the study of accounting within the context of a whole unified social system (Ryan, Scapens \& Theobald, 2002). This research generates indicators of business sustainability based on an understanding of business sustainability. The indicators generated are tools for change and if properly applied by the business community can result in a more sustainable life for all. Although this research does not fall within the critical accounting paradigm, it does present a solution to changing the system that can benefit the whole community, which is an attribute of the critical accounting paradigm (Ryan et al., 2002).

This research accesses a transdisciplinary field of knowledge in its development and process. Transdisciplinary concerns that which is between, across and beyond all disciplines; its goal is the understanding of the present world, of which one of the imperatives is the unity of knowledge (Nicolescu, 1999). This research embraces the principles of sustainability from the transdisciplinary field. More specifically it integrates the principles relating to spirituality, ecology and holism together with principles of business efficiency from cash/value flow and operations perspectives. The product is the presentation of indicators to determine if, and to what extent, business is taking cognisance of key sustainability factors.

This research applies the method of conceptual analysis (Du Toit, 2003) supported by an analytical study to provide a unifying framework illuminating practices of evaluation of sustainable business value. This framework is a tapestry of indicators, presented in key business focus areas, generated from current practice, which have been expanded on and adjusted by the researcher based on 12 years of corporate finance experience and supported by fundamental financial and sustainability principles. The research is structured as follows:

- A literature review conducted on an original and creative basis using books, articles, theses and current event material to ascertain the most appropriate definition and understanding of business sustainability in a holistic sense for the purpose of generating indicators. Such definition is explored in the context of: 
- balance (with respect to all stakeholders);

- harmony (leading to transparency and adequate and truthful disclosure);

- efficiency (economic/financial);

- creativity (innovation in terms of product, services, systems etc.); and

- adaptability (to change as required to survive and grow).

- A further literature review, which leads into an analytical study, demonstrates the relevance of cash/value flow to sustainability together with the stakeholder perspective and the need for holistic communication.

- Thereafter, pursuant to an analytical study of selected sustainability models, the research generates cash/value-flow-related indicators of business sustainability.

The analytical study is descriptive in nature in terms of which units of analysis (in other words, sustainability models) are selected and reviewed for the purpose of generating indicators. The units of analysis presented in section 4.5 are judiciously selected and comprise holistic sustainability models that are currently used in practice and encompass one or all of the principles of the stakeholder perspective, good corporate governance and/or the importance of cash flow dynamics. Each of the units of analysis aligns with the meaning of business sustainability as presented.

Ryan et al. (2003) contend that the basis of selection of case studies, and in this case an analytical study (including the units of analysis), should reflect the needs of the theory development. New ideals and levels of reality are being generated, and, accordingly, models that support such generation have been used as the units of analysis. Due to the developing nature of the field of business sustainability, this research deems it more direct, valid and effective at this stage to use practitioners who are the generators and implementers at the leading edge of new sustainability methodologies than to study businesses themselves.

\section{RESEARCH FINDINGS}

The relevant outcomes and findings of the literature review and analytical study are presented after each research question below.

\subsection{What are the understandings of business sustainability in a holistic sense?}

Sustainability refers to the condition where a business and economic activity 'meets the needs of the present without compromising the ability of future generations to meet their own needs' (Roth, 2008:11). Whiting and Bennett (2001) identify this as the original definition in the United Nation's Brundtland Commission report on Our Common Future (WCED, 1987). This definition of sustainability in the business context has stayed the same from 1987 to 2008 and it is a very simple and pure definition; it really is about sustaining existence. This research aims to maintain this meaning, whilst expanding the discussion around this definition.

Managers of a 'green venture' recognise the opportunity of creating a niche for their business or product(s) by embracing sustainable value concepts that provide them with an advantage in their industry (Johannson, 1994). The term 'green venture' can be aligned with a business that recognises that a cared-for environment and healthy economy are mutually dependent, i.e. that 
sustainability is important. The Framework for Integrated Reporting embraces the principles of sustainability and requires listed and public companies to produce an integrated report that is a 'holistic and integrated representation of its performance in terms of its finance and sustainability' (I0D, 2009; IRC, 2011). The Integrated Report needs to demonstrate to a business's stakeholders how it creates and sustains value in the short, medium and long term with reference to environmental, social, economic and financial issues (IRC, 2011). Johannson (1994) further notes that government and global business have accepted sustainability terminology in principle. The fact that King III and the Framework for Integrated Reporting place obligations on business to acknowledge sustainability issues indicates acceptance of the existence of these principles by a reasonable proportion of the business community. This research acknowledges this acceptance and further explores the meaning of business sustainability.

Based on a literature review, five principles have been identified as key to business sustainability. These five principles are presented in summarised form below and need to be considered alongside environmental, social, economic and political factors. They are interlinked and dependent on each other for optimal effectiveness:

- Stakeholder balance positions business as a conduit for improving the lives and conditions of all stakeholders. Its ability to deliver depends on the strength of its stakeholder relationships. Stakeholders of a business comprise, inter alia, customers, suppliers, the community, the environment, investors, financiers, management, employees and accountants (Tencati, Perrini \& Pogutz, 2004; Wingard, 2001). Davis (1991) develops the custodian role of business in terms of which it holds its resources in trust to make optimal use of them on behalf of the community. Business is viewed as a custodian of the wellbeing of the community, comprising its stakeholders. Perrini and Tencati (2006) argue that the sustainability of business hinges on the sustainability of its stakeholder relationships. Savitz (2006) embraces the idea that sustainability is the art of doing business in an interdependent world, which establishes the need to take care of an interconnected stakeholder base that is connected in various ways with the business. Stakeholders are interconnected and relationships with and within this base are fundamental for business to be sustainable.

- Transparency and harmony in a business environment comprehend the issues of openness, integrity and ethical values. Transparency in a business structure is required to maintain the normal rhythm of business (Choi Hoi Chee, 2007). Transparency opens the gates to a free-flowing, uncongested business style that enhances harmony and ease throughout the stakeholder base. Diedericks (2004) contends that real sustainability is generated from within through a process of self-awareness and reflection. King III (IOD, 2009) notes that stakeholders are indirect providers of capital, and as consumers and social citizens they are concerned about the planet's sustainability. They need assurance that a business is providing sustainable value which is provided through open communication and facilitated through a process of self-reflection.

- Supreme internal economic efficiency in sustainable business requires co-operation between all stakeholders, comprising the community and environment, to ensure a continuous developmental dynamic that results in sustainable business. Nicolescu (2008) introduces the concept of transdisciplinary into the sustainability definition, noting that the cosmic system, in all its dimensions, is the only sustainable system with the human being as the critical conduit. He goes on to say that the development of sustainable futures requires business to align with the overall movement of living nature and the cosmos, the 
overall ordered movement. To co-operate effectively and efficiently with the overall flow of living nature is interpreted by this research to mean to conduct business by embodying its inner essence in such a way as to create a perpetual natural motion as is seen in the neverceasing breaking of waves on the beach. There is ebb and flow and times of more or less intensity, yet the waves keep breaking. Another analogy is the survival dynamic of a truly bio-diverse ecosystem. If business can harness this creative motion it is ensuring a sustainable future as its business practice and generation of value becomes perpetual. According to Chow Hoi Hee (2007:1), based on his study of the Bhagavad Gita, an ancient Hindu spiritual text, 'business is about meeting market demand by having the capacity, capital and connections to sustain cash flow for the generation of profit.' Cash flow can be representative of the flow and generation of value within sustainable business. Integrating Nicolescu (2008) and Chow Hoi Hee's (2007) sustainability requirements, the emphasis is on the flow of cash and/or value through a business in alignment with the overall ordered movement.

- Innovation and creativity in relation to, inter alia, products, systems, management and the overall approach to business are necessary to ensure its sustainability. In terms of Kaplan and Norton's (1992) balanced scorecard, a company's ability to innovate, improve and learn influences the company's value. Creativity enables a business to generate and contribute to a niche in a sector thereby taking responsibility for its survival and future (Chow Hoi Hee, 2007).

- Business needs to adapt to change in order to create opportunities and to ensure its overall well-being. Davis (1991) observes that we are living in times of radical change and uncertainty in terms of which life is a continuity of change and never static. Post, Preston and Sachs (2002) address the need for change by presenting a relational view of the firm, based on the strategic view of the linkages with stakeholders. Such a view also sees that relationships rather than transactions are important. From the need for change follows the ability to change and adapt to new paradigms and business dynamics, specifically the view of nurturing relationships as opposed to purely maximising the outcome of any one transaction. This is a change with a longer-term perspective. Without the ability to change, change cannot take place effectively.

\subsection{What is the relevance of cash/value flow to business sustainability?}

Sustainable business value is identified by Savitz (2006) as an optimal flow of value or a process through all business stakeholders. Business value, as opposed to static value, comprises a perpetual efficient movement in the way business is conducted. The Framework for Integrated Reporting requires business to communicate its ability to create and sustain value throughout its broader stakeholder community in an integrated manner (IRC, 2011), thereby supporting the concept that value flows. The resources and assets that facilitate an efficient flow of value are in many cases intangible. Intangible assets comprise natural, social and human capital, more specifically, stakeholder relationships, transparency of business practice, integrity, ethics, trust, goodwill and other components identified as key principles for sustainability (Incite Sustainability, 2008; I0D, 2009).

Intangible capital and the interaction of its components need to generate sustainable business in order to justify and sustain business's own existence. Business processes and ethical practices are in essence intangible business resources and include, inter alia, the five principles of 
business sustainability highlighted in section 4.1, namely, stakeholder balance, transparency and harmony, supreme internal economic efficiency, innovation and creativity, and adaptability to change.

The principles of holism, being the ongoing synthesis of the parts as they unify and creatively change the whole (Smuts, 1926), are also embraced in recognising the relevance of cash/value flow to sustainable business. Without the ongoing movement of the parts in an ever-evolving manner, the whole will not attain its purpose, which is sustainability. For the purpose of this research, a business and all its stakeholders are viewed as the whole. In terms of these holistic principles, the entire capital base, comprising economic, social and environmental capital, needs to be considered when the sustainability of a business is assessed. In terms of Economic Value Added ${ }^{\circledR}$, intangible investments are put back onto the statement of financial position to determine genuine business performance (Stern, 2009). Lambrechts (2009) uses a similar approach in his holistic framework (built on the principles of holism), namely to consider the entire future resource base of a business as far ahead as a business can think and to determine what will keep the base, holistically speaking, as intact as possible. Everything that feeds in and out of the entire identified stakeholder base needs to be considered; sustainable development needs to be based on the whole.

Nicolescu (2008) notes that the only basis of reality is the overall ordered movement of the cosmos with which business needs to align in order to ensure sustainability. This research aligns the overall ordered movement with the principles that inform ecology, namely diversity, cooperation, dynamic networks, striving for equilibrium and continual environmental stimulus (Capra, 2002). Such principles highlight the need for fluidity in a business system and the significance of a perpetual co-operative movement that perpetuates sustainability. A comparison of the ecological principles with business systems is presented in TABLE $\mathbf{1}$ below.

\section{TABLE 1: Comparison of ecological principles to business systems}

\begin{tabular}{ll}
\hline \multicolumn{1}{c}{ Business systems } & \multicolumn{1}{c}{ Ecological principles } \\
\hline & Systems comprise networks These networks are, in turn, within networks. \\
& Their boundaries are there for the purpose of identity and \\
& individualisation, not separation (Capra, 2002:202). A network is an \\
& interactive net of dynamic variables, the boundaries of which are to allow \\
Networks & differentiation of function and niche operation as opposed to competitive \\
& isolation. Information and developments flow through boundaries as \\
& opposed to being limited in movement. Value is developed within networks \\
& and allowed to flow to other networks to ensure value creation. \\
\hline \multirow{3}{*}{ Cycles } & Systems respond to the stimulus and input of their environment (Capra, \\
& 2002). Continuous communication and flows of all forms between the \\
& entire stakeholder base and business allow business to operate effectively \\
& and efficiently, generating sustainability. \\
\hline Energy source and flow & The movement of energy in a system is essential for its survival as energy \\
& moves to change states of imbalance to balance (Capra, 2002). A \\
& sustainable business system needs to transform challenges into \\
& productivity in harmony with its stakeholder base. Lack of harmony is a \\
catalyst for a shift to a more harmonious state. A business system needs to \\
be an energetically dynamic system that is able to mobilise change.
\end{tabular}




\begin{tabular}{ll}
\hline \multicolumn{1}{c}{ Business systems } & \multicolumn{1}{c}{ Ecological principles } \\
\hline & $\begin{array}{l}\text { capital to generate further energy/value flow to sustain the business. } \\
\text { Energy is the life force or chi of a business system that may manifest in } \\
\text { dynamic tangible and intangible forms }\end{array}$ \\
\hline & The more diverse the system, the greater its immunity (Capra, 2002). The \\
& multiplicity of systems within a business system will ensure its ultimate \\
& well-being. As in ecology, the more diverse a system, the more co- \\
operative interaction is possible and so more prolific life and flow of value \\
is ensured.
\end{tabular}

\section{Source: Capra (2002:202); Commentary generated by this research}

A business process needs to ensure it generates genuine value for stakeholders (as opposed to depleting value), which requires that the business process is as efficient as possible with an identified value stream for each product, where the minimisation of interruptions can ensure that value is created (Savitz, 2006). Profit is no longer the focus, but rather sustainable creation and flow of value. Business needs to move towards creating value through the customer experience as opposed to maximising transactional value (Tyrer, 2009). The concept of dynamic value flow supports the generation of this intangible value, which is the customer relationship in terms of which genuine value creation is the primary target. Optimal cash/value flow taking cognisance of the need to maximise stakeholder value is a critical ingredient of the business engine as depicted.

\subsection{Why address all stakeholders as opposed to primarily the investor base?}

There are two perspectives when assessing business value; one is the stakeholder perspective and the other the shareholder perspective. Relationships with stakeholders depict a significant part of the intangible capital base of a business; these resources are the generators of ongoing value for a business.

In terms of the shareholder perspective, profit to shareholders is of primary importance and value is measured by share price and economic profit (Value Based Management, 2009). As the stakeholder perspective places responsibility towards stakeholders first, trust is critical and contribution to the common goodwill creates business value (Value Based Management, 2009). This research aims to integrate the shareholder value perspective into the stakeholder value perspective. This will be done by recognising that a business is a network of interacting stakeholders and that stakeholder management is paramount to business sustainability, yet financial efficiency and return/flow of value to all stakeholders (including shareholders) based on business and other risks are equally important.

This research presents the purpose of a sustainable company as that of custodian for its community of stakeholders. King III (IOD, 2009:23) identifies the primary reason for the existence of business as creating value; the concept of value creation has evolved beyond purely shareholder value to encompass stakeholder value. In most cases, value is depicted in one way or another by cash flow: for example, a customer pays for a product, raw material and services 
are paid for in cash and the value of work-in-progress can be determined on a cash value basis at most junctures in its process. The Circle of Business Life diagram presented in FIGURE $\mathbf{1}$ depicts the interactive flow of value throughout the stakeholder community.

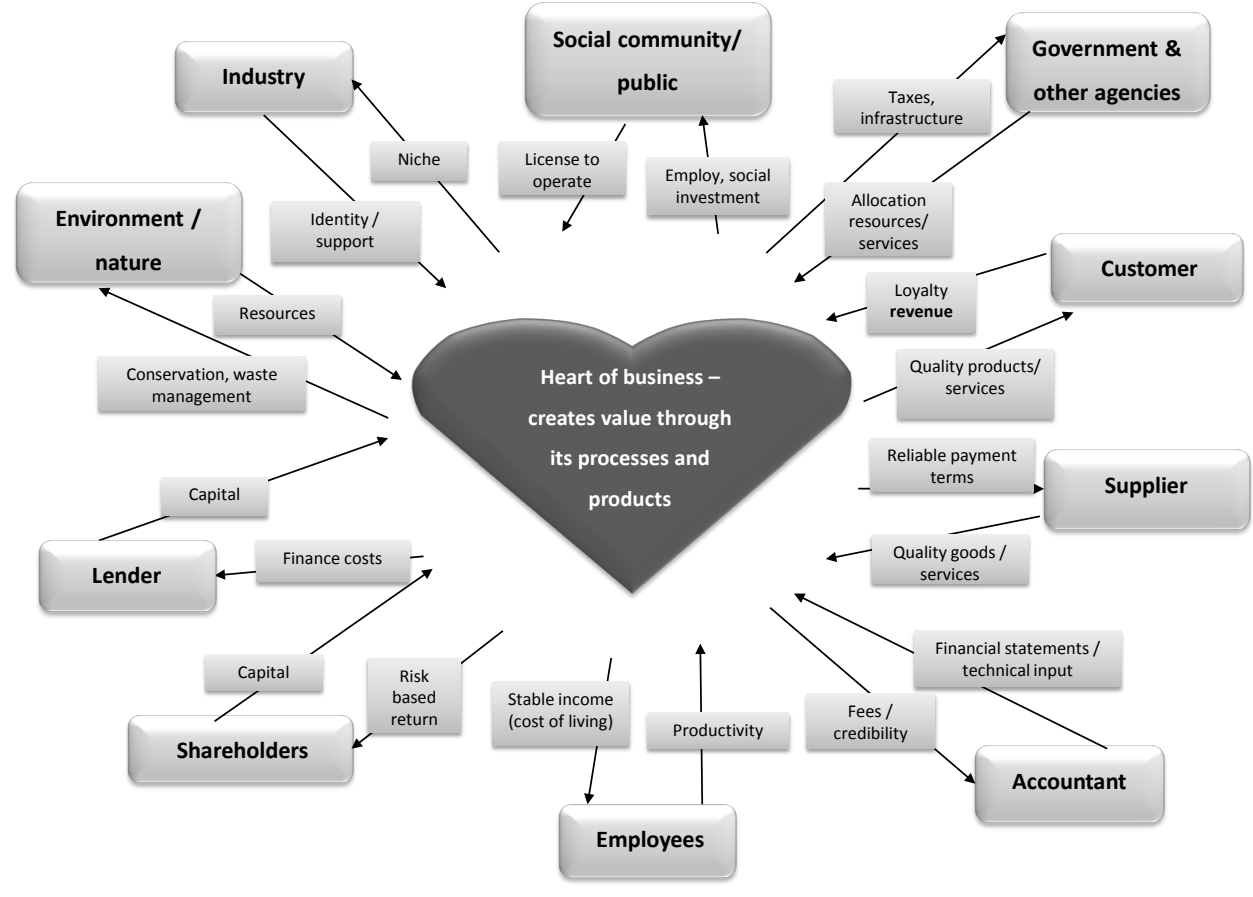

FIGURE 1: The circle of business life

Source: The stakeholder categories are drawn from the Framework: users of financial statements (IASB, 2009:19). The value and/or cash flows are drawn from issues identified in this research. This research collates the various stakeholders together into the business model and demonstrates the value flows throughout the business process.

\subsection{Should financial accounting not provide a more holistic communication?}

Terry (2009) points out that sustainability is not just a fleeting interest, but rather the future of business success and mankind as a whole; he proposes that chartered accountants need to take a greater interest in sustainability issues and sustainability reporting. This view is taken to a deeper level in King III (IOD, 2009), where it is acknowledged that sustainability is more than just reporting on social and environmental matters; rather governance, strategy and sustainability are inseparable. Accordingly, sustainability reporting is a holistic business matter. Business is not viewed solely as a vehicle to generate profit that must report profitrelated information to its shareholders, but rather business is responsible to society for its actions and needs to report relevant information to all stakeholders.

As Stern (2009) has noted, the principles of accounting were developed from the relationship 
between lenders and borrowers - in other words, between the financial supporters of the business and the business itself. This does not call for or allow a broader statement of financial position including intangibles, comprising social and natural capital, because the lenders are only interested in how tangibly secure their money is in the business and whether the interest can be paid. Currently the statement of financial position comprises primarily tangible (and controlled intangible) resources, yet the greatest value of a business is its intangible stakeholder-related resources, for example, customer relationships, community support, management integrity and reputation, which are not included in the statement. Even if such resources cannot be capitalised and recognised on the statement of financial position, their relevance to a business and its strategy needs to be communicated to stakeholders.

Taking cognisance of the five principles that form the understanding of business sustainability as presented in section 4.1, together with the importance of cash/value flow in sustainable business, the level of business sustainability can be reflected through indicators that encapsulate the essence of intangible value. This research has generated a selection of cash/value-flow-related business sustainability indicators.

\subsection{What are cash/value-flow-related indicators that reflect business sustainability?}

This research has performed an analytical study of four sustainability models/methodologies for the purpose of generating cash/value-flow-related indicators of business sustainability. The units of analysis comprise innovative sustainability models and methodologies currently applied or used in practice. These units of analysis have been judiciously selected using the following criteria:

- models that acknowledge the stakeholder perspective;

- models that are developed and organically driven by the needs of the users and the passion of the designers (the creation of a niche in the sustainability industry);

- models that are deeper in their analysis of sustainability than the triple-bottom-line accounting approach; and

- holistic and all-encompassing models in their approach to business sustainability.

Each of the four selected models has contributed to the development of the understanding of business sustainability in the literature review. These units and the means of engagement with each model are presented below in TABLE 2.

TABLE 2: Sustainability models as units of analysis

\begin{tabular}{|c|c|}
\hline Sustainability Model & Engagement with model \\
\hline $\begin{array}{l}\text { Sustainability Framework and Indicators } \\
\text { for the holistic framework developed by } \\
\text { Lambrechts (2009) based on the } \\
\text { principles of holism as defined by } \\
\text { Smuts(1962). Lambrechts consults on } \\
\text { sustainability practices from Cape Town. }\end{array}$ & $\begin{array}{l}\text { Lambrechts presented a workshop for approximately eight } \\
\text { delegates in Johannesburg in } 2009 \text { on his approach to } \\
\text { sustainability implementation in business and sustainable } \\
\text { land reform. The workshop was facilitated by SAICA. The } \\
\text { researcher was provided with an opportunity to engage with } \\
\text { Lambrechts with regard to the practical application of the } \\
\text { model. }\end{array}$ \\
\hline $\begin{array}{l}\text { SustainAbility's Sustainable Business } \\
\text { Value (C) Model by SustainAbility ( } 2001)\end{array}$ & $\begin{array}{l}\text { SustainAbility has published a report, Buried Treasure, which is } \\
\text { a report forming part of its Engaging Stakeholders series }\end{array}$ \\
\hline
\end{tabular}




\begin{tabular}{ll}
\multicolumn{1}{c}{ Sustainability Model } & \multicolumn{1}{c}{ Engagement with model } \\
\hline $\begin{array}{l}\text { from Buried Treasure. SustainAbility } \\
\text { consults as a group to major corporate } \\
\text { clients on sustainability. }\end{array}$ & $\begin{array}{l}\text { (SustainAbility, 2001:1). The Sustainable Business Value (C) } \\
\text { Model has been studied, analysed and presented in Buried }\end{array}$ \\
& $\begin{array}{l}\text { Treasure. The researcher reviewed and critically analysed the } \\
\text { report and related articles. }\end{array}$ \\
\hline
\end{tabular}

The Sustainability Evaluation and Reporting System (SERS) evolved by Perrini and Tencati (2006) - 'an integrated methodology aimed at monitoring and tracking from a qualitative and quantitative viewpoint the overall corporate performance according to a stakeholder framework, in line with SMEs managerial requirements.'
The model and methodology has been developed by SPACE (the Research Centre of Bocconi University (Milan, Italy) on Risk, Security, Occupational Health and Safety, Environment and Crisis Management) based on approximately 15 years of research and is presented in an article in Business Strategy and the Environment, 2006, volume 15. The researcher engaged with the article and performed complementary reviews of other articles on the value-added statement that forms a key component of the Sustainability Evaluation and Reporting System.
Economic Value Added ${ }^{\circledR}$ by Stern (2009). Stern Stewart was founded in 1982 by Joel M. Stern and G. Bennett Stewart III, and has grown into a business with a reputation of assisting companies increase their market value (Stern, 2009). EVA® is a primary product.
Joel Stern presented a seminar facilitated by SAICA on EVA ${ }^{\circledR}$, at which the researcher was able to gather an extensive understanding of the underlying principles and application of the model. In addition, the researcher has analysed certain other articles written by Joel Stern and others on EVA ${ }^{\circledR}$ and reviewed the Stern Stewart website to the extent relevant.

\section{Source: Generated by this research}

Each unit of analysis has been assessed on the following basis:

- reviewed and interpreted in terms of sustainability and value methodologies;

- explored, understood and documented sustainability and value indicators to the extent that they are cash/value-flow-related; and

- expanded on, amended and added to identified cash/value-flow-related indictors, if required, to complement the understanding of business sustainability.

The following eight key business focus areas are identified in which specific cash- and valueflow-related indicators of business sustainability are presented. The focus areas have been collated from the sustainability methodologies of Lambrechts (2009), SustainAbility (2001), Perrini and Tencati (2006), and Stern (2009) (the methodology informing each focus area is identified):

- enterprise value based on EVA®: Stern (2009);

- value-added statement and investment in stakeholder relationships: Perrini and Tencati (2006);

- revenue: SustainAbility (2001);

- operational efficiency (including gross profit analysis and marginal reaction): Lambrechts (2009), Perrini and Tencati (2006) and SustainAbility (2001);

- efficient cash management: Lambrechts (2009);

- access to capital: SustainAbility (2001);

- human capital investment: SustainAbility (2001) and Stern (2009); and

- reputational capital: SustainAbility (2001). 


\section{KEY BUSINESS FOCUS AREAS AND RELATED INDICATORS}

A brief discussion on each key business focus area together with specific cash/value-flowrelated indicators is presented below:

\subsection{Enterprise value based on EVA ${ }^{\circledR}$}

EVA ${ }^{\circledR}$ determines business value by incorporating intangibles and adjusting financial data to a cash-flow basis (Johnson, 2007). EVA® of a business is the additional business value, based on adjusted net operating profit after tax and achievable future growth, created after servicing the cost of capital (debt and equity) (Stern, 2010). In terms of the proposed stakeholder model, EVA ${ }^{\circledR}$ should be created for all stakeholders to ensure sustainable business, therefore EVA $^{\circledR}$ should be considered with regard to the potential contribution to each category of stakeholder, for example, reduced product prices, contribution to external infrastructure costs and social investment. It should be noted that $\varepsilon V{ }^{\circledR}$ needs to be generated through efficiency and not exploitation of any resource. If all external costs were internalised, stakeholder considerations included and socially related investment taken into account, $\varepsilon V{ }^{\circledR}$ should be minimal, provided that the business is run with optimal efficiency.

\subsection{Value-added statement}

The value-added statement measures the (financial) value-add generated and distributed by a business to the different stakeholder groups (employees, financiers, state/local authorities, community, environment) or invested in the business (retained income) (Perrini \& Tencati, 2006). Customers supply the revenue to the value-added equation and suppliers receive payment for supplying necessary goods and services. Thereafter the value created is distributed among various stakeholder groups. Based on this analogy, all stakeholder groups can be represented in the one statement. A cash-based value-added statement (a value-added statement that articulates with the statement of cash flows of a business and is preferred by some companies (Stainbank, 2009)) reflects the investment in and/or contribution from all relevant stakeholder categories on a cash and not an accrual basis. The cash-based valueadded statement can be used as an indicator of business sustainability to observe whether all relevant stakeholder groups are represented, how evenly value created is distributed between the stakeholder groups and how this could be more balanced.

\subsection{Revenue (total cash received in the form of revenue)}

Revenues are the fuel of corporate machinery (SustainAbility, 2001). Revenues are key cashflow drivers of a business, as they energise the business system; without revenue, there is no business. Changes in the revenue stream can be due to new products/services, pricing, new markets, change of market share of an existing product, and redefinition of product/service (SustainAbility, 2001). Diversity of revenue sources in line with the principles of ecology as defined by Capra (2002) is important to ensure sustainability. King III (IOD, 2009) notes that, among other things, a company's sustainability depends upon the sustainability of the industry in which it operates. Chow Hoi Hee (2007) further develops this by emphasising the importance of creating a niche in an industry in order to be sustainable.

Revenue-based cash/value-flow-related indicators generated by this research include: 
- adequate diversity with regard to small versus large clients; revenue from diverse sources; geographical diversity; and different products/services sold;

- percentage contribution in terms of total revenue to the industry;

- description of the niche created by the business;

- growth of business niche's contribution to the sector in terms of revenue;

- well-being of the sector in the economy;

- growth in revenue from individual new products tracked year on year;

- total new product revenue relative to total revenue;

- new product revenue as a return on research and development costs;

- percentage contribution from new client sales relative to total revenue;

- contribution from the stable customer base to total revenue;

- total sales year on year;

- documented knowledge of customers and their needs and expectations; and

- proof of communication with customers.

\subsection{Operational efficiency}

Operating efficiency is the ability of a company to turn inputs into productive outputs in a costeffective manner and is the indicator of a company's health, measured in two ways, namely, minimising costs and maximising resource productivity (SustainAbility, 2001). Revenue is the entry point of most money and value into the business cycle. How efficiently is it utilised from this point and how effectively does it generate wealth? When considering minimisation of costs and enhancement of productivity per unit of currency, the entire business/product process needs to be considered. The value generated from a business flow as opposed to a stop/start process needs to be experienced and optimised (Savitz, 2006).

Operational efficiency-based cash/value-flow-related indicators generated include:

- gross margin analysis;

- operating margin analysis and reaction assessment;

- assessment of the flow dynamic in the business process - identify any stop in the process or areas where energy/value is diluted;

- process limitation assessment - identify limitations for increased sales/net profit;

- assessment of degree of compromise to any stakeholders in the process; and

- value costs/benefits of external impacts.

\subsection{Efficient cash management}

The cash conversion cycle $=$ operating cycle - average payment period $=$ average age of inventory + average collection period - average payment period; it is reflected in months and relates directly to the cash resources needing to be invested to support the working capital cycle (Megginson, Smart \& Gitman, 2007). There is a wealth of hidden value in efficient cash management of a business. An inefficient working capital cycle that requires more cash than an efficient one imposes costs on the business. Steyn-Bruwer and Hamman (2007) identify the risks of overtrading (too much growth without adequate cash resources to sustain it) as revenue growth rates, inventory and accounts receivable levels, percentage of credit sales, and finance costs.

Cash management-based cash/value-flow-related indicators generated include:

- the cash conversion cycle for the current year and past four years; 
- accounts receivable period (average accounts receivable / sales $\times 365$ days);

- accounts payable period (average accounts payable / cost of sales $\times 365$ days);

- inventory turnover period (average inventory / cost of sales $\times 365$ days);

- collected sales / cash conversion cycle;

- profit after tax (add: depreciation, amortisation and profit/loss on sale of fixed assets) / collected sales $\times 100$; and

- cash flow from operations (before deducting dividends) / collected sales.

\subsection{Access to financial capital}

SustainAbility (2001) identifies two components that determine availability of capital and the cost thereof, namely, the risk of the investment, and the expected return, which is higher for higher risk. The risk profile of a business is a direct measure of its sustainability: how susceptible are its resources to damage or erosion due to inadequate care (SustainAbility, 2001)? How best is risk measured in terms of cash-flow-related factors? Increased risk has a direct negative impact on the discount rate (increasing the required cost of capital) applied to any business, which will reduce the present value of future cash flows (Stern, 2009). A business's sustainability will be jeopardised if it does not have access to sufficient capital or its capital is too expensive.

Financial capital-based cash/value-flow indicators generated by this research include:

- risk (of all types) is a primary driver of the availability of capital and its resultant cost and is measured through the following cash-flow-related indicators:

0 incremental effect of differing discount rates on future cash flows; and

- potential and actual cash outflows or loss of inflows due to excessive risk; risk that could be mitigated through sustainable business management.

- the cost of capital, comprising the after-tax cost of debt and the cost of equity, expressed as percentages and actual cash outflow amounts on an annual basis;

- the actual cost of capital relative to the expected optimal cost of capital for such a business in an optimal risk situation;

- the internal capital-generating capacity of the business (cash generated from operations before deducting dividends paid) relative to capital to operate; and

- cash generated from operating activities before dividends, interest and taxes paid relative to interest payable for the period.

\subsection{Human capital investment}

Human and intellectual capital is the accumulated knowledge and skill of the employees of a business and can be measured by investment in employee training and development; the innovative ability of the company; the history of attracting and retaining staff; and staff satisfaction surveys (SustainAbility, 2001). King III (IOD, 2009) identifies development and management of human capital as key to business sustainability and notes that employees' value and productivity in the new age are key success differentiators. When assessing a business's investment in human capital, new products developed, return on research and development and revenue can be reviewed to the extent that they demonstrate loyalty and trust from human capital.

Human capital-based cash/value-flow indicators generated by this research include:

- sustainable collected revenue from innovation in products/services and processes;

- sustainable monetary cost savings and efficiencies from innovation in products/ 
services and processes;

- the proportion of staff costs capitalised to research and development and other intangible asset development;

- total monetary value of staff costs relative to collected revenue year on year;

- range of annual salaries paid and number of staff members at each level;

- sustainable value of investment in staff development;

- staff recruitment and laying-off costs;

- number of new staff on an annual basis relative to stable portion of staff; and

- number of departing staff on an annual basis relative to stable portion of staff.

\subsection{Reputational capital}

Companies with a good reputation, which is linked to their role in the community, attract better employees, pay less to suppliers and accrue other benefits; yet few companies take a quantifiable approach to reputation management (IOD, 2009). Economic, social and environmental capital treated responsibly ensures sustainability - reputation, a primary asset, is then protected (IOD, 2009). Jackson (2004) acknowledges that although much effort goes into valuing and presenting a business's capital assets, by far the greatest asset is a business's reputation. The return on good reputation occurs in the form of customer attraction and hence revenue generation (SustainAbility, 2001). The cost of building reputational capital can be recorded, yet assessment will be the return on such investment, which ultimately contributes to a positive cash flow of the business through, for example, increased revenues and preferential rates in the market place.

Reputational capital-based cash/value-flow-related indicators generated include:

- cash generated from operations (per statement of cash flows);

- payment to a stable/loyal employee base relative to total employee payments;

- cash paid to loyal suppliers (noting discounts received) relative to total payables;

- revenue from loyal customers relative to total collected revenue;

- cash invested in reputation and trust development;

- investment in harmonising the work environment;

- community investment and enterprise development; and

- investment in stakeholder engagement.

\section{SUMMARY AND CONCLUSION}

Based on an analytical study of four sustainability models, cash- and value-flow-related indicators have been generated in the following eight key business focus areas:

- Enterprise value based on $E V A^{\circledR}$ - EVA $^{\circledR}$ should be available for all stakeholders, including those deemed external to the business. The way in which EVA® is shared equitably between stakeholders is a sustainability indicator.

- Cash-based value-added statement - is an indicator of sustainability as it indicates to what extent value created is shared among the stakeholders.

- Revenue - is the engine of business; accordingly indicators relating to the sustainability of revenue are pointers to sustainable business.

- Operational efficiency - depicts the efficiency with which revenue is converted into useful business value and cash flow. Indicators relating to the efficiency of this 
conversion process are sustainability indicators.

- Efficient cash management - cash is required to support a working capital cycle. Inefficiencies in the cash management cycle translate into inefficient application of business cash resources.

- Access to capital - is dependent on business risks, which determine the availability and cost of capital, both of which affect the flow of business value.

- Human capital - is the knowledge and worth of the employees of a business that translate directly into sustainable business generation.

- Reputational capital - is a fundamental intangible asset for business success and directly supports the revenue cycle.

The primary purpose of this research is to generate cash- and value-flow-related indicators of business sustainability from a stakeholder perspective. In order to generate such indicators, a deeper meaning of business sustainability was required. Business can be defined as custodian of the community that is required to ensure a flow of genuine value to all stakeholders to contribute to their well-being. Business sustainability encompasses balanced stakeholder engagement, transparency, economic efficiency, creativity and the ability to change. The overall ordered movement of the cosmos is identified as the blueprint for sustainability and can be found in the divine workings of nature. Business needs to mimic the dynamics of nature to attain sustainability.

\section{LIST OF REFERENCES}

Babbie, દ. \& Mouton, J. (2001). The Practice of Social Research. Cape Town: Oxford University Press. Burger, J.H. \& Hamman, W.D. (1999). The relationship between the accounting sustainable growth rate and the cash flow sustainable growth rate. South African Journal of Business Management, 30(4), pp. 101-109.

Capra, F. (2002). The Hidden Connections: Integrating the Biological, Cognitive, and Social Dimensions of Life into a Science of Sustainability. New York: Doubleday.

Chow Hoi Hee, C. (2007). A holistic approach to business management: perspectives from the Bhagavad Gita. Singapore Management Review, 29(1), pp. 73-85.

Davis, J. (1991). Greening Business: Managing for Sustainable Business. Cornwall: TJ Press Ltd.

Diedericks, J. (2004). Sustainability, the real challenge lies within. Convergence, 2(3), pp. 128-129.

Du Toit, L. (2003). Conceptual Analysis. In D. Rossouw (ed.). Intellectual tools: skills for the human sciences, $2^{\text {nd }}$ edition. Pretoria: Van Schaik (pp. 22-36).

International Accounting Standards Board (IASB). (2009). Framework - Framework for the preparation and presentation of financial statements. London: IASCF Publications Department.

Incite Sustainability. (2008). Reporting on development that really works, and works. Starting a discussion on sustainability reporting for development financing in the SADC. [0n-line] Available: http://www.incite.co.za/wp-content/uploads/2011/02/2007_DBSAreport-LR-2-3.pdf. (Accessed 5 December 2011) 
Institute of Directors in Southern Africa (IOD). (2009). King Report on Corporate Governance in SA 2009 (King III). Prepared by King Committee on Governance. Parkland: Institute of Directors in Southern Africa.

Integrated Reporting Committee (IRC). (2011). Discussion paper: Framework of Integrated Reporting and the Integrated Report. Prepared by IRC. [On-line] Available:

http://www.sustainabilitysa.org/Portals/0/IRC\%20 of\%20SA\%20Integrated\%20Reporting\%20Guide\% 20Jan\%2011.pdf. (Accessed 23 April 2012)

Jackson, K.T. (2004). Building Reputational Capital: Strategies for Integrity and Fair Play that Improve the Bottom Line. New York: Oxford University Press.

Jarvis, R., Curran, J., Kitching, J. \& Lightfoot, G. (1999). The use of qualitative and quantitative criteria in the measurement of performance in small organisations. Journal of Small Business and Enterprise Development, 7(2), pp. 123-134.

Johannson, L. (1994). Profits from green ventures. Hamilton, 68(7), pp. 17-20.

Johnson, S. (2007). Creating value. Student Accountant, pp. 40-43

Kaplan, R.S. \& Norton, D.P. (1992). The balanced scorecard: measures that drive performance. Harvard Business Review, 70(1), pp. 71-79.

Lambrechts, J. (2009). SAICA Sustainable organisations workshop. Johannesburg, South Africa.

Megginson, W.L., Smart, S.B., \& Gitman, L.J. (2007). Corporate Finance, $2^{\text {nd }}$ edition. USA: Thomson South-Western.

Nicolescu, B. (1999). The transdiciplinary evolution of the university condition for sustainable development. [0n-line] Available: http://nicol.club.fr/ciret/rechnom/rech.htm. (Accessed 5 December 2011)

Nicolescu, B. (2008). Transdiciplinary and sustainable futures. Sustainable Futures: What's left? What's right? What's next? $11^{\text {th }}$ International Winelands Conference, 16-18 April 2008, Stellenbosch, South Africa.

Perrini, F. \& Tencati, A. (2006). Sustainability and stakeholder management: the need for new corporate performance evaluation and reporting systems. Business Strategy and the Environment, 15, pp. 296-308.

Post, J.E., Preston, L.E. \& Sachs, S. (2002). Managing the extended enterprise: the new stakeholder view. California Management Review, 45(1), pp. 6-28.

Roth, H.P. (2008). Using cost management for sustainability efforts. Wiley Interscience. [On-line] Available: http://www.interscience.wiley.com. (Accessed 5 December 2011)

Ryan, B., Scapens, R.W. \& Theobald, M. (2002). Research method and methodology in Finance and Accounting. China: C\&C Offset Printing Co Limited.

SAICA - The South African Institute of Chartered Accountants.

Savitz, A.W. (2006). The Triple Bottom Line. San Francisco: Jossey-Bass.

Shani, A.B., Sena, J.A. \& Olin, T. (2003). Knowledge management and new product development: A study of two companies. European Journal Innovation Management, 6(3), pp. 137-150.

Smuts, J. (1926). Holism and Evolution. London: Macmillan \& Co Limited. 
Stainbank, L. J. (2009). The value added statement: does it add value? Meditari Accountancy Research, 17(2), pp. 137-149.

Stern, J. M. (2009). SAICA 2009 EVA seminar. March 2009, Johannesburg, South Africa.

Stern Stewart \& Co. (2010). Economic value added. [0n-line] Available:

http://www.sternstewart.com/ ?content=proprietary\&p=eva\&page=2. (Accessed 22 March 2010)

Steyn-Bruwer, B.W. \& Hamman, D.W. (2007). Identifying South African listed companies involved in overtrading. Meditari Accounting Research, 15(2), pp. 43-63.

SustainAbility, Business Case and United Nations Environment Programme. (2001). Buried Treasure: Uncovering the Business Case for Corporate Sustainability. London: SustainAbility.

Swilling, M. (2001). Managing the triple bottom line. Productivity, December/January, pp. 22-24.

Tencati, A., Perrini, F. \& Pogutz, S. (2004). New tools to foster corporate socially responsible behaviour. Journal of Business Ethics, 53, pp. 173-190.

Terry, G. (2009). Businesses have an obligation to account to society. [0n-line] Available: http://www.saica/tabid/695/itemid/1461/language/en-za/Businesses-have-an-obligation-toaccount-to-society.aspx. (Accessed 20 May 2009)

Tyrer, N. (2009). Crucial factor is to build trust - Accenture. Business Day, 27 November, p. 15.

Value Based Management. (2009). Shareholder value perspective versus the stakeholder value perspective. [0n-line] Available: http://www.valuebasedmanangement.net/faq

shareholder_stakeholder_perspective.html. (Accessed 20 May 2009).

Whiting, M.A. \& Bennett, C.J. (2001). The Road to Sustainability: Business's First Steps. New York: Conference Board.

Wingard, H.C. (2001). Financial performance of environmentally responsible South African listed companies. Unpublished PhD thesis. Pretoria: University of Pretoria.

World Commission on environment and development (WCED). (1987). Our Common Future. New York: Oxford University Press. 